\title{
Cerebrospinal fluid analysis in infectious diseases of the nervous system: when to ask, what to ask, what to expect
}

\author{
0 exame do liquido cefalorraquidiano em doenças infecciosas do sistema nervoso: \\ quando pedir, o que pedir, o que esperar \\ Luís dos Ramos Machado ${ }^{1,3}$, José Antonio Livramento ${ }^{2,3}$, Liliana Scaff Vianna4
}

\begin{abstract}
Cerebrospinal fluid (CSF) analysis very frequently makes the difference to the diagnosis, not only in relation to infections but also in other diseases of the nervous system such as inflammatory, demyelinating, neoplastic and degenerative diseases. The authors review some practical and important features of CSF analysis in infectious diseases of the nervous system, with regard to acute bacterial meningitis, herpetic meningoencephalitis, neurotuberculosis, neurocryptococcosis, neurocysticercosis and neurosyphilis.
\end{abstract}

Keywords: cerebrospinal fluid, central nervous system, bacterial meningitis, herpes simplex virus, meningoencephalitis, meningeal tuberculosis, cryptococcal meningitis, neurocysticercosis, neurosyphilis.

\section{RESUMO}

O exame de líquido cefalorraquidiano (LCR) é frequentemente o elemento determinante para o diagnóstico não somente de infecções mas também de outras doenças do sistema nervoso, tais como doenças inflamatórias, desmielinizantes, neoplásicas e degenerativas. Os autores reveem alguns aspectos práticos e importantes quanto ao papel do exame de LCR em meningites bacterianas agudas, meningoencefalite herpética, neurotuberculose, neurocriptococose, neurocisticercose e neurossífilis.

Palavras-Chave: líquido celalorraquidiano, sistema nervoso, meningites bacterianas, encefalites por herpes vírus, tuberculose meníngea, meningite criptococócica, neurocisticercose, neurossífilis.

Cerebrospinal fluid (CSF) analysis is a classic tool for diagnosing infectious diseases of the nervous system (NS).

The main diseases that can be diagnosed among NS infectious diseases are acute meningitis, acute meningoencephalitis and chronic meningitis.

\section{Acute bacterial meningitis}

You may be aware that a lumbar puncture may save the life of a patent if correctly indicated. There is no other diagnostic tool that can be used in these patients'.

\section{When should I ask for a lumbar puncture in a case of acute bacterial meningitis? \\ In classical clinical manifestations²:}

- Fever mainly of unclear origin or from a toxemic syndrome: in $90-95 \%$ of the cases;

- Headache and vomiting (intracranial hypertension): in 80-90\% of the cases;

- Nuchal rigidity, Kernig and Brudzinski signs (meningeal syndrome): in $80-90 \%$ of the cases;

- Mental status compromised: 17;

- All three syndromes (meningeal, toxemic and intracranial hypertension): $44 \%$; two of these syndromes: $95 \%$. In special clinical presentations $s^{3,4}$ :

- In elderly individuals: (a) less frequent clinical manifestations: fever (65\%); headache (50\%); meningeal syndrome (55\%); and (b) more frequent findings: mental status alterations (80\%);

\footnotetext{
${ }^{1}$ Professor Livre-Docente do Departamento de Neurologia; Coordenador do LIM-15, Faculdade de Medicina da Universidade de São Paulo, FMUSP, São Paulo SP, Brasil;

${ }^{2}$ Professor Assistente Doutor, Departamento de Neurologia, FMUSP, São Paulo SP, Brasil;

${ }^{3}$ Sócio-Diretor do Laboratório Spina-França, LSF, São Paulo SP, Brasil.

${ }^{4}$ Médica Neurologista, LSF, São Paulo SP, Brasil.

Correspondence: Luís dos Ramos Machado; Praça Amadeu Amaral 47 / conj. 33; 01327-010 São Paulo SP - Brasil; E-mail: luisrmachado@globo.com
} 
- In children, meningitis should be systematically suspected and lumbar puncture needs to be requested more frequently, in cases of fever, irritability, lethargy, vomiting or seizures;

- In home-care patients: underlying pathological conditions and special care needs may change the susceptibility to infectious agents that has to be considered in each case;

- Sometimes it may take longer for meningitis to become evident (12 to 24 hours) in a patient with an unsuspected immunological deficit or with particular susceptibility to a bacterial agent, thus making the diagnosis more difficult.

\section{When should lumbar puncture be avoided?}

- When there are clear signs of systemic infection by meningococcus. You can introduce bacteria into the CSF system through the lumbar puncture;

- When there is intracranial hypertension and the toxemic syndrome is mild or absent. You can ask for an image and await clearer definition;

- You need to have a brain image before asking for CSF analysis when focal signs seen on neurological examination suggest a cerebral mass lesion or massive edema that may put the patient at risk; or in cases of Glasgow $<10$, seizure or papilledema.

\section{What should I ask for in a CSF analysis and what is really important?}

It is very important to know:

- Whether the opening pressure is elevated. This suggests that blood-brain-barrier (BBB) breakdown has occurred, and the disease tends to be more severe in such cases;

- Whether there is any inflammatory reaction in the CSF sample. This is the most important parameter for define whether meningitis is present or not. In a situation of immunodepression or in a premature newborn, this evidence may be lacking;

- Whether neutrophils predominate, generally accounting for more than $90 \%$ of the profile. The presence of neutrophils is evidence that bacterial antigens may be present in the CSF sample;

- Whether the glucose concentration is low. Glucose consumption through the process of phagocytosis of bacteria by neutrophils causes a low glucose concentration in the CSF sample. Thus, in a simple manner, while the glucose level is low, bacteria are being destroyed by neutrophils;

- Whether the lactate concentration is high. This is due to a local anaerobic metabolism resulting from clearance of bacteria by neutrophils. It is of great interest to determine the lactate concentration (which is independent of the serum levels and reflects only the CSF metabolism), in parallel with the glucose concentration (which is continuously influenced by the serum glucose concentration). Thus, a low glucose concentration in the CSF when the lactate concentration is normal means that no glucose consumption is occurring in the CSF and that hypoglycemia is likely to be the problem;

- Whether the adenosine-deaminase (ADA) activity is normal or increased. Normal ADA means that meningitis alone is present; increased ADA means that encephalitis is associated with the meningitis;

- Whether latex antigen is present. Latex antigen detection is a very interesting test, since it may enable almost immediate diagnosis of the causal agent. Tests from different commercial sources are now available for pneumococcus, meningococcus (A, B, C, Y and W135), Hemophilus-b and Streptococcus-b;

- Whether PCR (polymerase chain reaction) to search for the classical community agents is needed. These tests have good sensitivity and specificity, but usually the diagnosis can be made through other, less expensive methods. PCR is used more to detect the genomic material of bacteria (such as Listeria) that occur less frequently and are harder to isolate or grow in culture media.

\section{What can I expect?}

- The classical CSF syndrome in cases of acute bacterial meningitis comprises hypertension, neutrophilic inflammatory reaction, increased proteins and low glucose/ high lactate. This syndrome may show many variations according to the etiological agent, severity, previous antibiotic use, patient immunity and recurrence;

- It is accepted that all methods for identifying bacteria through CSF analysis, including cultures, have much more chance of success when the inflammatory reaction has a clear neutrophilic type;

- Gram staining can identify bacterial type and morphology (sensitivity 50\%; low specificity). Morphology and staining by Gram method in bacterial meningitis may be not so easy as it appears and the same bacteria may show variation from case to case;

- Success in detecting antigens from the classical community bacteria, through the latex test (sensitivity 49-78\%; specificity $>95 \%$ );

- Culture growth (sensitivity 50-70\%; high specificity), when no antibiotics were taken previously;

- Positive genomic tests (from PCR): sensitivity 80-95\%; specificity $>95 \%$.

\section{Acute viral meningitis}

Viral meningitis is a benign infection of the CNS, and the CSF diagnosis is usually very easy. There are just a few noteworthy observations:

- High percentages of neutrophils may be observed in meningitis caused by enteroviruses, especially by coxsackievirus. These neutrophil levels decrease dramatically after the first 24 hours; 
- PCR for enteroviruses is available in real time and allows rapid and safe diagnosis of enterovirus-caused meningitis;

- Repeated episodes of meningitis are frequently caused by the herpes genital virus HSV-2. The diagnosis needs to be suspected and the patient must be actively asked. Immunological tests are very sensitive and specific;

- $\mathrm{ADA}$ needs to be investigated, and it is very important to distinguish benign viral meningitis from tuberculosis, from fungal or herpetic meningoencephalitis and even from lymphoma.

\section{HSV-1 encephalitis}

This is a very severe disease, with high mortality and morbidity rates. Early diagnosis is imperative in order to allow neurologists to treat these patients successfully ${ }^{5,6}$.

\section{When should I ask for a lumbar puncture?}

- In cases of abrupt changes of behavior or personality with or without nuchal rigidity, with low fever and with normal magnetic resonance imaging (MRI);

- In cases of patients without overt intracranial hypertension but with altered mental status, together with two of the following signs: fever $>37.5^{\circ} \mathrm{C}$; convulsions; focal neurological signs; or suggestive MRI.

\section{What should I ask for in a CSF analysis and what is really important?}

- Full CSF analysis: xanthochromia; cytology; biochemistry (proteins, glucose, lactate, ADA and protein electrophoresis); exclusion microbiological tests;

- Specific anti-HSV-1 antibodies (IgG and IgM);

- PCR for HSV-1 (the gold standard).

\section{What can I expect?}

- Xanthochromia caused by red blood cell breakdown, since HSV-1 encephalitis causes a necrotic and hemorrhagic cerebral lesion;

- More than 5 cells $/ \mathrm{mm}^{3}$.

- Increased proteins, usually to more than $80 \mathrm{mg} / \mathrm{dL}$;

- Normal or slightly altered glucose/lactate concentrations;

- Increased ADA activity. The ADA increase may maintain some form of relationship with the extent of the brain lesion;

- Positive PCR for HSV-1 (sensitivity >95\%; specificity $>98 \%$ ). This sensitivity is higher in the first four days;

- Specific IgG antibodies. They may be absent from the first CSF sample, but usually show a strong increase after 10-12 days. A significant increase in IgG titers over this time period has a diagnostic value similar to positive PCR;

- Specific IgM antibody detection is seen less frequently in HSV-1 encephalitis. When the viral particles pass from the latent to the reactive phase, IgM levels increase, but insufficiently to reach the detection limit.

\section{Neurotuberculosis}

Tuberculous meningitis (TBM) is a form of extrapulmonary tuberculosis that is usually severe. In most cases, it consists of chronic meningoencephalitis with high mortality and morbidity ${ }^{5}$. Death occurs in two principal ways: through associated intracranial hypertension and secondary vasculitis.

\section{When should I for ask a lumbar puncture?}

- In cases of chronic general health decline, weakness, chronic pulmonary disease and low fever, but without overt intracranial hypertension;

- In cases of non-hypertensive hydrocephaly;

- In cases of "viral" meningitis lasting for more than two or three weeks;

- In cases of "viral" meningitis with abrupt and rapid neurological deterioration. In such cases, previous MRI (to search for possible vascular lesions) is mandatory;

- In HIV-positive cases of immune reconstitution inflammatory syndrome (IRIS).

\section{What should I ask for in a CSF analysis and what is really important?}

- Full CSF analysis: opening pressure; cytology; biochemistry (proteins, glucose, lactate and ADA);

- Ziehl-Nielsen staining;

- Acid-fast bacilli culture. These bacteria grow very slowly, taking up to 45-60 days;

- PCR for Mycobacterium tuberculosis.

\section{What can I expect?}

- More than 5 cells $/ \mathrm{mm}^{3}$ (90-100\% of the cases);

- Presence of neutrophils (0-100\% of the cases). Neutrophils are seen in CSF when Koch bacillus antigens reach the CSF space, after release from a tuberculous granuloma or abscess. Immediately after this migration to the CSF, neutrophils percentage in the cytological profile may reach almost $100 \%$. Thereafter, the immune system rapidly implements clearance of these bacteria and the percentage values of neutrophils decline in parallel. The neutrophils may even disappear completely. Thus, the percentage of neutrophils seems to be a true marker for the presence of tuberculous bacteria antigens in CSF;

- Increased proteins (>100 mg/dL), in 60-70\% of the cases;

- Moderate decrease in glucose concentration (<40 mg/dL), in $70-85 \%$ of the cases;

- Moderate increase in lactate concentration (>25 mg/dL), in $75-80 \%$ of the cases;

- Increased ADA (>6.0) in 90-100\% of the cases;

- Ziehl-Nielsen staining for acid-fast bacilli positive in $0-10 \%$ of the cases;

- Positive culture for Mycobacterium tuberculosis, in 30-70\% of the cases; 
- PCR positive for genomic sequences of Mycobacterium tuberculosis: sensitivity 49-85\%; specificity 94-100\%. The stronger the presence of tuberculous bacterial antigens in the CSF is, the greater the neutrophil concentration that ensues and the higher the PCR sensitivity becomes.

\section{Neurocryptococcosis}

Cryptococcosis is an opportunistic chronic infection that affects the NS mainly in patients with immunodeficiency ${ }^{5}$. It is caused most frequently by Cryptococcus neoformans variety neoformans and by Cryptococcus neoformans variety gattii. The latter is responsible for a more severe clinical form.

\section{When should I ask for a lumbar puncture?}

- In cases of severe intracranial hypertension without mass effect;

- In cases of non-hypertensive hydrocephaly;

- In cases of "tuberculous meningitis" that are unresponsive to anti-tuberculous treatment;

- In HIV-positive cases of immune reconstitution inflammatory syndrome (IRIS);

- In cases of neurocryptococcosis with intracranial hypertension that is hard to control, especially when visual loss is imminent. In these cases, repeated lumbar puncture is required preceding the shunt surgery, at least three times a week and if possible in different lumbar spaces, using a 20 or $21 \mathrm{G}$ traumatic (Quincke) needle.

\section{What should I ask for in a CSF analysis and what is really important?}

- Full CSF analysis: opening pressure; cytology; biochemistry (proteins, glucose, lactate and ADA);

- China ink test;

- Latex test for Cryptococcus neoformans;

- Sabouraud culture: growth ranging from a few days to one month.

\section{What can I expect?}

CSF general analysis is very similar to the analysis in neurotuberculosis cases, except for:

- Positive search for soluble Cryptococcus antigen through the latex test: sensitivity 95\%; specificity 100\%;

- Positive culture for Cryptococcus neoformans: in 70-90\% of the cases.

\section{Neurocysticercosis}

The most important factors to be considered in diagnosing neurocysticercosis (NC) are the clinical manifestations, the MRI and CT images and the CSF-specific tests ${ }^{7}$.

$\mathrm{NC}$ has two main forms based on clinical, imaging and laboratory data: (a) NC in cerebral parenchymal form; (b) $\mathrm{NC}$ in CSF space form ${ }^{8}$. In about $20-30 \%$ of the cases, the two forms may appear together in the same patient.
When should I ask for a lumbar puncture in cases of the parenchymal form of NC?

- In cases of NC with severe or persistent headache in which no mass effect is detectable through imaging;

- In cases of non-hypertensive degenerative cists with an annular or nodular appearance and without active cysts presenting scolex. The differential diagnosis with tuberculosis, mycosis or even cancer may be difficult.

When should I ask for a lumbar puncture in cases of the CSF space form of $\mathrm{NC}$ ?

- In cases of chronic meningitis;

- In cases of non-hypertensive hydrocephaly;

- In acquired cases of recurrent epileptic crises, with normal MRI and CT;

- In cases of meningeal thickening or arachnoiditis;

- In all cases of clinical intracranial hypertension without focal signs, in areas endemic for NC. Accurate image investigation must precede the lumbar puncture.

\section{What should I ask for in a CSF analysis and what is really important?}

- The opening pressure, which is more important in CSF space NC;

- The classical components of CSF syndrome in NC cases, as described by Lange in 1936: increased number of cells; presence of eosinophils; and detection of specific antiTaenia antibodies, investigated through a routinely used Weinberg reaction';

- Transitory intense neutrophil profile in the acute phase of cyst degeneration;

- Deceased glucose and increased lactate concentration in more severe cases;

- Increased gamma globulin in protein electrophoresis;

- Specific antibody search, using more than one immunological reaction: currently indirect immunofluorescence, passive hemagglutination and ELISA. The classical enzyme-linked immunoelectrotransfer blot (EITB) is only a good test for serum diagnosis of taeniasis, and not for diagnosing $\mathrm{NC}$;

- Taenia antigens, especially in NC cases with negative antibody tests.

\section{What can I expect?}

- The results that can be expected from CSF analysis in NC cases are as shown in Tables 1 and $2^{10}$ :

- Taenia antigen searches have been found to be positive in $57.1 \%$ of parenchymal NC cases ${ }^{11,12}$.

\section{Neurosyphilis}

CSF analysis is the preferred method for diagnosing neurosyphilis $(\mathrm{NS})^{13}$. The prevalence of NS has been increasing over recent decades, mainly as a comorbidity with AIDS $^{14,15,16}$. 
Table 1. CSF analysis in NC patients.

\begin{tabular}{lcc} 
CSF test & parenchymal NC (\%) & CSF space NC (\%) \\
\hline Hypertension & 22.2 & 21.1 \\
Increased cells & 0 & 100 \\
Neutrophils & 0 & 52.6 \\
Eosinophils & 0 & 94.7 \\
Increased proteins & 27.8 & 84.2 \\
Decreased glucose & 5.6 & 36.8 \\
Increased ADA & 0 & 73.7 \\
\hline
\end{tabular}

Table 2. Immunological reactions: anti-Taenia antibodies in CSF.

\begin{tabular}{lcc} 
Immunological reaction & $\begin{array}{c}\text { parenchymal } \\
\text { NC (\%) }\end{array}$ & $\begin{array}{c}\text { CSF space } \\
\text { NC (\%) }\end{array}$ \\
\hline Weinberg (complement fixation) & 0 & 57.9 \\
Indirect immunofluorescence & 11.1 & 78.9 \\
Passive hemagglutination & 61.1 & 84.2 \\
ELISA & 38.9 & 94.7 \\
\hline
\end{tabular}

\section{When should I ask for a lumbar puncture in NS cases?}

1. In late syphilis cases, even when no neurological symptoms or signs are detected;

2. In syphilis patients at every phase in which neurological symptoms appear;

3. In HIV-positive patients with some neurological complaints.

\section{What should I ask for in a CSF analysis and what is really important?}

- The classical full CSF analysis ${ }^{17}$, including protein electrophoresis (PEP). Surprisingly, in a recently described criteria, PEP was not included as an important diagnostic tool, or for establishing the evolution profile of NS patients after penicillin treatment ${ }^{14,18,19}$;

- The VDRL (Venereal Disease Research Laboratory) test to search for antibodies against the cardiolipin-lecithincholesterol antigen in CSF. This is the most important reaction for diagnosing NS;

- Atleast one treponemal reaction:Fluorescent Treponemal Antibody - absorption (FTA abs), passive hemagglutination, ELISA or Treponema pallidum particle agglutination (TPPA). Most of the antigens used in these reactions come from saprophytic treponemes, since Treponema pallidum does not grow in culture media ${ }^{5,18,19}$;

- $\quad$ PCR for Treponema pallidum, which is the most up-todate test for diagnosing $\mathrm{NS}^{5}$.

\section{What can I expect?}

- The CSF analysis is abnormal in $70 \%$ of NS patients. The main results from CSF general analysis are described in Table $3{ }^{20}$ :
Table 3. CSF analysis in NS patients.

\begin{tabular}{lcc} 
CSF test & Frequency (\%) & Median \\
\hline Increased cells & 66.1 & 16.5 cells \\
Increased proteins & 85.5 & $57.0 \mathrm{mg}$ \\
Increased gamma globulin & 95.1 & $27.0 \%$ \\
\hline
\end{tabular}

- In active parenchymal NS forms, glucose levels may be decreased in up to $11.3 \%$ of the cases;

- Increased gamma globulin is more frequent and intense in cases of progressive general paralysis, reaching percentage values as high as $62 \%$ of the $\mathrm{PEP}^{20}$;

- The VDRL test is a very specific reaction for diagnosing NS, but has low sensitivity ( 30\%). Thus, in diagnosing NS, other general data from CSF analyses are important, particularly the increased number of cells;

- Treponemal tests may be used to rule out the diagnosis of asymptomatic NS ${ }^{5,16,17,19}$. Because they have high sensitivity, these tests can detect serum antibodies even at relatively low concentrations, which can reach the NS through the blood-brain barrier in patients without NS;

- PCR for Treponema pallidum has low sensitivity (50\%), probably because the T. pallidum concentration in the brain is known to be very low;

- The decrease in the number of cells is the simplest and most precise criterion for assessing the improvement of NS after treatment: the cell numbers tend to become normal within six months. In HIV-positive patients, however, a more important and persistent increase in cell numbers is frequently found ${ }^{16}$;

- Increased protein levels may persist for a longer time, up to a matter of years, without any relationship with the success of the treatment;

- Persistent VDRL test titers after specific treatment may be also a criterion for instituting new treatment;

- Successful treatment for parenchymal NS is marked by a slow but constant decrease in the percentage of gamma globulin in CSF. Persistently high or increasing percentages of gamma globulin may be a criterion for new treatment for NS (Nitrini, 1987) ${ }^{20}$.

In conclusion, CSF analysis is still the most useful tool for diagnosing NS infectious diseases.

CSF analysis very frequently makes the difference to the diagnosis, not only in relation to infections but also in other diseases of the NS such as inflammatory, demyelinating, neoplastic and degenerative diseases. However, CSF should not be taken to be a test performed in isolation but should always be interpreted together with clinical and imaging data. 
1. Scott LA, Tintinalli JE, Brewer KL, Salgado CD. Lumbar punctures for suspected meningitis in adults. Infect Dis Clin Pract 2008;16:298-302.

2. Van de Beek D, de Gans J, Tunkel AR, Wijdicks EFM. Communityacquired bacterial meningitis. N Engl J Med 2006;354:44-53.

3. Davies, JE. Changing world of acute bacterial meningitis 2013. $65^{\text {th }}$ Annual Meeting American Academy of Neurology. Syllabi. On CD ROM 2013.

4. Van de Beek D, Drake JM, Tunkel AR. Nosocomial bacterial meningitis. N Engl J Med 2010;362:146-154

5. Zunt JR, Baskwin KJ. Chronic and subacute meningitis. Infectious diseases Continuum Lifelong Learning in Neurology 2012;18(6).

6. Reiber H, Peter JB. Cerebrospinal fluid analysis: disease-related data patterns and evaluation programs. Neurol Sci 2001;184:101-122.

7. Machado LR. The diagnosis of neurocysticercosis: a closed question? Arq Neuropsiquiatr 2010;68:1-2.

8. Bueno EC, Machado LR, Livramento JA, Vaz AJ. Cellular imune response of patients with neurocysticercosis (inflammatory and noninflammatory phases). Acta Tropica 2004;91:205-213.

9. Lange O. [Cerebrospinal fluid in cysticercosis of the central nervous system] O liquido cephalo-rachidiano na cysticercose do systema nervoso central. Rev Neurol Psiquiat São Paulo 1936;2:3-11.

10. Machado LR, Livramento JA, Vaz AJ, Bueno EC, Mielli SR, Bastouly V, Nóbrega JPS. IgG intrathecal synthesis and specific antibody index in patients with neurocysticercosis. Arq Neuropsiquiatr 2002;60:395-399.

11. Abraham R, Livramento JA, Leite CC, Pardini AX, Vaz JA, Machado LR. Neurocysticercosis: relationship between Taenia antigen levels in CSF and MRI. Arq Neuropsiquiatr 2010;68:7-11.
12. Abraham R, Pardini AX, Vaz AJ, Livramento JA, Machado LR. Tenia antigens detection in the cerebrospinal fluid of patients with neurocysticercosis and its relationship with clinical activity of the disease. Arq Neuropsiquiatr 2004;62:756-760.

13. Ghanen KG. Neurosyphilis: a historical perspective and review. CNS Neurosci Therap 2010;16:e157- e168.

14. CDC Sexually Transmitted Diseases Treatment Guidelines, 2010. www.cdc.gov/mmwr/pdf/rr/rr5912.pdf. Accessed: 08.05.2013.

15. Wilcox RD. The challenge of neurosyphilis in HIV. HIV Clin 2009;21:5-6.

16. Marra CM, Maxwell CL, Collier AC, et al. Interpreting cerebrospinal fluid pleocytosis in HIV in the era of potent antiretroviral therapy. BMC Infect Dis 2007;7:37.

17. Lange 0 . [The cerebrospinal fluid in luetic affections of the nervous system] O liquor nas afecções luéticas do sistema nervoso. In: O liquido cefalo-raquidiano em clínica. Edições Melhoramentos, São Paulo, 1938.

18. Marra CM, Maxwell CL, Tantalo L, et al. Normalization of cerebrospinal fluid abnormalities after neurosyphilis therapy: does HIV status matter? Clin Infect Dis 2004;38:1001-1006.

19. Marra CM, Maxwell CL, Tantalo LC, et al. Normalization of serum rapid plasma reagin titer predicts normalization of cerebrospinal fluid and clinical abnormalities after treatment of neurosyphilis. Clin Infect Dis 2008;47:893-899.

20. Nitrini R, Spina-França A. [High-dose intravenous penicilin-G in the treatment of neurosyphilis: a study of 62 patients. II Cerebrospinal fluid evaluation] - Penicilinoterapia intravenosa em altas doses na neurossílis: estudo de 62 casos. II Avaliação do líquido cefalorraqueano. Arq Neuropsiquiatr 1987;45:231-241. 